\title{
Purple hands in multiple system atrophy
}

\section{Global anhidrosis with preserved acral sweating}

A
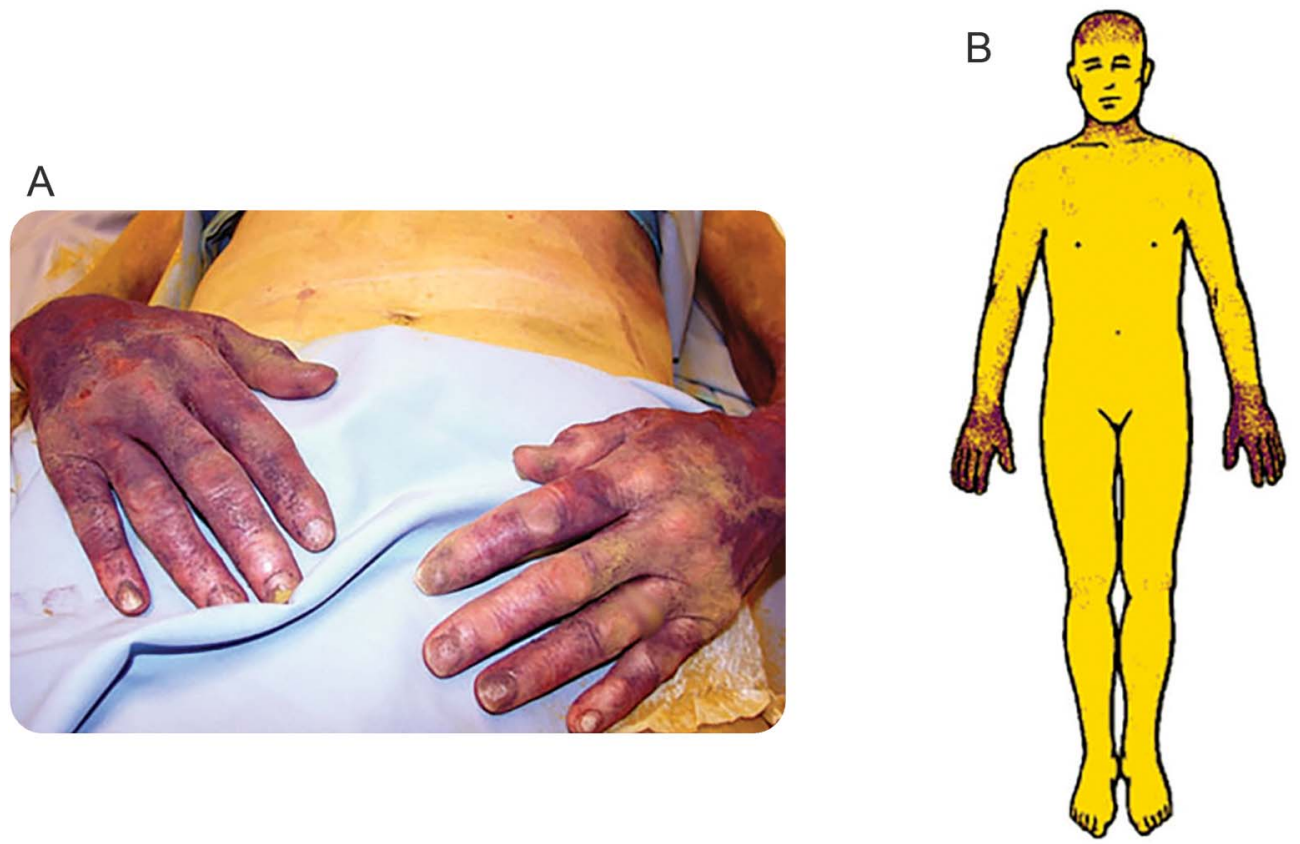

Sweating is shown in purple by the alizarin indicator powder, which was spread evenly over the exposed body surface. Sweating was present over the hands (A) with sparse areas of preserved sweating on the neck and forehead shown in the digitized image (B). Calculated body surface anhidrosis was $94 \%$.

A patient developed parkinsonism at age 60 years followed by autonomic involvement with orthostatic hypotension and urinary incontinence, consistent with multiple system atrophy (MSA). Quantitative sudomotor axon reflex test revealed intact postganglionic sudomotor function, while thermoregulatory sweat test (figure) showed global anhidrosis, indicating a preganglionic/central lesion of sudomotor pathways consistent with MSA. ${ }^{1}$ Acral sweating was preserved.

Global anhidrosis with acral sparing is a thermoregulatory sweat pattern observed in MSA. The purple hands may be akin to the cold hands sign in MSA. ${ }^{2}$ Mechanistically, this could indicate selective preservation of sympathetic pathways, greater sweat gland density, or denervation supersensitivity affecting the hands.

Elizabeth A. Coon, MD, Robert D. Fealey, MD, Eduardo E. Benarroch, MD, Paola Sandroni, $M D, P h D$, Phillip A. Low, MD, Wolfgang Singer, MD

From the Mayo Clinic, Rochester, MN.

Author contributions: Dr. Coon: drafting/revising the manuscript for content, study design, analysis or interpretation of data. Dr. Fealey: drafting/revising the manuscript for content, analysis or interpretation of data. Dr. Benarroch: drafting/revising the manuscript for content, analysis or interpretation of data. Dr. Sandroni: drafting/revising the manuscript for content, analysis or interpretation of data. Dr. Low: drafting/revising the manuscript for content, analysis or interpretation of data. Dr. Singer: drafting/revising the manuscript for content, study design, analysis or interpretation of data, study supervision.

Study funding: No targeted funding reported.

Disclosure: The authors report no disclosures relevant to the manuscript. Go to Neurology.org for full disclosures.

Correspondence to Dr. Coon: coon.elizabeth@mayo.edu

1. Low PA. Evaluation of sudomotor function. Clin Neurophysiol 2004;115:1506-1513.

2. Klein C, Brown R, Wenning G, Quinn N. The "cold hands sign” in multiple system atrophy. Mov Disord 1997;12:514-518. 


\section{Neurology}

\section{Purple hands in multiple system atrophy: Global anhidrosis with preserved acral sweating}

Elizabeth A. Coon, Robert D. Fealey, Eduardo E. Benarroch, et al.

Neurology 2016;86;2314

DOI 10.1212/WNL.0000000000002778

\section{This information is current as of June 13, 2016}

\section{Updated Information \& Services}

References

Subspecialty Collections

\section{Permissions \& Licensing}

Reprints including high resolution figures, can be found at: http://n.neurology.org/content/86/24/2314.full

This article cites 2 articles, 0 of which you can access for free at: http://n.neurology.org/content/86/24/2314.full\#ref-list-1

This article, along with others on similar topics, appears in the following collection(s):

All clinical neurophysiology

http://n.neurology.org/cgi/collection/all_clinical_neurophysiology Autonomic diseases

http://n.neurology.org/cgi/collection/autonomic_diseases

\section{Cerebellum}

http://n.neurology.org/cgi/collection/cerebellum

Multiple system atrophy

http://n.neurology.org/cgi/collection/multiple_system_atrophy

Parkinson's disease/Parkinsonism

http://n.neurology.org/cgi/collection/parkinsons_disease_parkinsonism

Information about reproducing this article in parts (figures,tables) or in its entirety can be found online at:

http://www.neurology.org/about/about_the_journal\#permissions

Information about ordering reprints can be found online:

http://n.neurology.org/subscribers/advertise

Neurology ${ }^{\circledR}$ is the official journal of the American Academy of Neurology. Published continuously since 1951, it is now a weekly with 48 issues per year. Copyright (O 2016 American Academy of Neurology. All rights reserved. Print ISSN: 0028-3878. Online ISSN: 1526-632X.

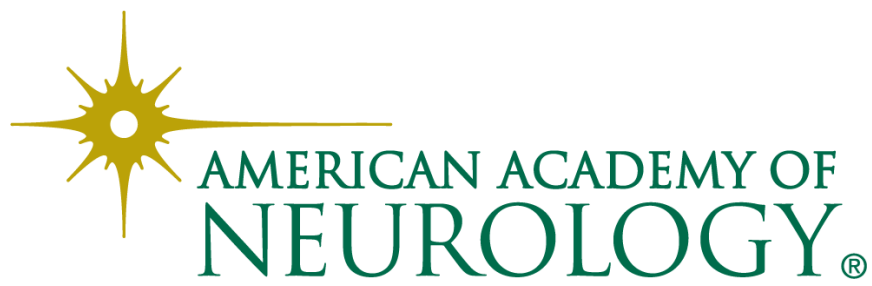

